\title{
A Comparative Study of the Selected Administrative Practices at Public and Private Sector Universities of Pakistan
}

\author{
Bibi Asia Naz \\ Lecturer, Department of Education Awku Mardan, Ph.D Scholar At Institute Of Education \\ And Research, Gomal University D.I.Khan \\ Dr. Umar Ali Khan \\ Director, Institute Of Education And Research Gomal University D.I.Khan

\begin{abstract}
Dr. Rahmat Ullah Shah
Assistant Professor, Institute Of Education \& Research, University Of Science \& Technology, Bannu, Pakistan
\end{abstract}

Javed Iqbal

Ph.d Scholar, Institute of Education and Research Gomal University, D.I.Khan

Accepted: January 26, $2012 \quad$ Published: March 17, 2012

Doi:10.5296/ijld.v2i1.1521ＵRL: http://dx.doi.org/10.5296/ijld.v2i1.1521

\begin{abstract}
The study aims to compare the administrative practices of public and private sector universities of Khyber Pakhtoonkhwa and Punjab. The researcher randomly selected 160 academicians and 160 administrators from two public and two private universities of each province Khyber Pakhtoonkhwa and Punjab. The data was collected through a questionnaire consisted of 32 domains. The main findings of the study are: There is no significant difference between the opinions of academicians and administrators of public and private sector universities about the amendments in the act/statute, the HEC influence in Administrative matters, the members selection of different bodies, tenure of different bodies, the decision making practice, the staff selection. While significant difference was found between the opinions of academicians
\end{abstract}




\section{$\Lambda$ Macrothink}

and administrators of public and private sector universities about the procedure for irregularities. It is evident that there is lack of a proper procedure for dealing with irregularities in both sector universities.

Key Words: Administrative Practices, Academicians, Administrators, Universities.

\section{Introduction}

Education and specially the higher education is a major national investment in social and economic progress. Its constituent elements must be selected and managed as serious and concrete investment items. The university should be laboratory for experimentation, a training ground to equip the students with skills and knowledge to enter and change society (Vohra A.M., 1990). The transmission of existing knowledge and the extension of the boundaries of knowledge to new generations are of course the key functions of a university. "The development and transmission of knowledge has traditionally been seen as a central governing role and responsibility of universities" (Loh Benjamin, 2003). According to Quddus (cited by (Haider, 2008) Studied that "The basic function of a college or university is to preserve, enhance, criticize, and transmit knowledge and to foster creative capacities." Universities have two key purposes; these are research and education.

Theoretically, universities' main function and mission is to provide and spread knowledge and ideas within communities (Loh, Tang, Menkhoff, Chay, \& Evers, 2003).

There are three main responsibilities of universities which are teaching, research and provisions for the availability of budget. (www.eric.ed.gov)

"Institutions of higher education have the main responsibility for equipping individuals with advanced knowledge and skills required for positions of responsibility in government, business, and other professions." (Pakistan, 1998-2010)

Quality education depends on the good administration. Administration plays a pivotal role in the promotion of education. It is the main responsibility of administration and management to accomplish the objectives of an institution. If administration of education is not enhanced or it is not geared to the new needs, changes and challenges, the system or organization cannot achieve the desired objectives or accomplish the target (Mohanty, 1998).

Necessarily, in any particular organized enterprise, administration is conditioned by the nature of the operation itself, whether it be a product or a service, and by the history or tradition of the enterprise. This circumstance is especially evident in the instances of university administration. (Singh, 1978). In the last two decades or so, Pakistan and developing countries have been giving attention to the problems of university administration (Adeeb, 1996) . (Aeth, 1975) States that it is due to lack of proper administration and it has clear effects on the development of Higher Education. The resources are available for university development, but the administrators cannot achieve the best possible results (Abdullah, 1992).

Prior to 1980's the higher education in Pakistan was the sole responsibility of the government. There were a few institutions of higher education in the private sector from 1985 onwards; many institutions have been established in the private sectors that are providing higher education in different fields. Private and public sector Universities, definitely compete, and in many ways. 
The quality of higher education totally depends on the efficient and proper administration of universities.

Every university has a constitution act on the basis of which it operates. The constitution act lay down the university's function and responsibilities, determines the various authorities through which it govern itself, prescribes the areas of rule making, allows for affiliation and inspection of colleges, and locates up the offices of administration. The act provides a skeleton, and blood activity to local discretions. The changes in the constitutions of each university are necessary to meet the changing situations and requirements (Singh, 1978).

The Statutes of any university describe the constitution, the powers and functions of the authorities.

All institution are organized differently, nearly all universities have a board of trustees; a president, chancellor, or rector; at least one vice president, vice-chancellor, or vice-rector; and deans of various divisions. Public university systems are ruled over by government-run higher education boards. They review financial requests and budget proposals and then allocate funds for each university in the system. They also approve new programs of instruction and cancel or make changes in existing programs. They also plan for the further coordinated growth and development of the various institutions of higher education in the country. Private universities are privately funded and generally have a broader independence from state policies. (www.en.wikipedia.org). Universities are statutory organizations established under state of central acts or they are registered institution notified as deemed universities. The internal governance of the universities is through its main bodies namely court/senate, executive council/syndicate, academic council and the finance committee (Mishra, 2007)

For execution of university matters syndicate, academic council, selection board, finance and planning committee, advance study and research board manage academic and other day-to-day activities in universities. These bodies set educational standards, goals, rules and regulations and establish the policies and procedures to carry them out. They also supervise and support faculty members, librarians, coaches, affairs and management of the property of the university. They develop academic programs, standard of teaching, monitor students, educational progress, train and motivate teachers and other staff, manage guidance and other students services, administer record keeping, planning \& development, prepare budget, handle relation with parents, prospective and current students, and the community, and performs many other duties. They may handle all these functions effectively if the members are well-trained, equipped with new knowledge, management skills and decision power. (Anwar, 2008). The activities of the different sections in university are coordinated and directed centrally, though the arrangements may be vary greatly. There is an academic head and most frequently an assembly of members of the university (senate, council, etc.) (www.eric.ed.gov)

The basic element of a university consists of academic and administrative staff.

"Studies include: an examination of the present supply and future prospects for attracting competent faculty members in sufficient number to meet requirements in various areas; appropriate action should be taken to provide an attractive and competitive faculty salary; reasonable teaching and research assignments; and fringe benefits to attract top ranking educators" (Allen, (1988)) 
Appointment of faculty members is a very sensitive process as it has a considerable impact on students, departments, and the whole University for years to come. Dissatisfaction with the selection and appointment of teachers in many places is one of the most frequently voiced graviences of the university teachers. Lack of confidence in the fairness of selection procedures is general and representations again alleged favoritism, discrimination and in-breeding in the appointment of teaching staff are an everyday affair. In many places, a large number of posts of lecturers are filled temporarily on and adhoc basis and the teachers are then allowed to continue for long periods of time to enable them succeed eventually in getting priority in regular appointments. The practice keeps out many better qualified persons from competing. In many universities too much of in-breeding is rampant, attribute largely to the defective composition of selection committees and the role played by the concerned departmental heads. To these problems (Vohra A.M., 1990) suggested a central machinery for recruitment.

In building up a major university, it will be necessary to conduct an energetic search throughout the country for outstanding and promising young people for its teaching and research staff. And for this (Vohra A.M., 1990) suggest that each department or faculty should have a specially appointed personnel advisory committee. Which would work in close collaboration with the appointing authorities of the university to find faculty members in fields in which it is already distinguished or in which it seeks distinction.

The faculty recruitment process has some common objectives:

- To recruit and hire the best available and most qualified candidate for each position,

- While providing an equal opportunity for consideration to all qualified and interested persons, paying particular attention to reach out to members of groups who have historically not held such positions,

- And consistently applying and documenting the University's policies and procedures for recruitment and selection of faculty and staff. (faculty recruitment and selection guide, www.google.com)

The following steps are involved in the recruitment process.

Step 1: Identifying a vacant position to be filled

Step 2: Developing a Results-Oriented Position Description

Step 3: Formal Request for posting approval process

Step 4: Developing and Implementing a Recruitment Strategy

Step 5: Search Committee

Step 6: Screening Candidate resumes and applications

Step 7: Interview and Selection Process

Step 8: Reference Checks

Step 9: Summations and Recommendations

Step 10: Job Offer (faculty recruitment and selection guide, www.google.com)

"Decision making can be regarded as an outcome of mental processes (cognitive process) leading to the selection of a course of action among several alternatives." (Anwar, 2008)

According to Matthai et al., (cited by (Anwar, 2008), the university has its apex levels bodies such as senate, syndicate, academic council, faculties and board of studies, planning committees to take decisions. It has the administrators like Vice Chancellor, registrar, provost, deans, Directors, and head of the departments. He mentions that in decisions such as 
programme selection, faculty selection, planning and allocating budgets and formulating the academic policies, there should be participation of all the members of statutory bodies. But in Pakistan it appeared that the structure of universities did not offer a great degree of autonomy to members to make decisions

It was observed that always top university structures are linked with the "outside world" and in some cases is even part of it. And found that this relation exist with Government, other institution of higher education, teacher training institutions, the training of nurses and technicians, other research institutions (www.eric.ed.gov). "The Higher Education Commission (HEC), formerly the University Grant Commission, is the primary regulator of higher education in Pakistan. It also facilitated the development of higher educational system in Pakistan. Its main purpose was to upgrade universities in Pakistan to be centers of education, research and development. The HEC has played a leading role towards building a knowledge based economy in Pakistan by giving out hundreds of doctoral scholarships for education abroad every year.

\section{OBJECTIVES OF THE STUDY}

Following were the objectives of the study.

- To investigate the opinions of Stakeholders about the selected administrative practices in universities of Pakistan.

- To compare the views of administrators and academicians about the selected administrative practices (the amendments in the statute, the HEC influence in Administrative matters, the selection of different bodies, tenure of different bodies, the Decision Making practice, and the staff selection and procedure for irregularities) of public and private sector universities of Pakistan.

\section{Hypotheses of the study}

1. There is no significant difference between the opinions of academicians and administrators of public and private sector universities about the amendments in Act/Statute.

2. There is no significant difference between the opinions of academicians and administrators of public and private sector universities about the HEC influence in Administrative matters.

3. There is no significant difference between the opinions of academicians and administrators of public and private sector universities about the selection of different bodies.

4. There is no significant difference between the opinions of academicians and administrators of public and private sector universities about tenure of different bodies

5. There is no significant difference between the opinions of academicians and administrators of public and private sector universities about the Decision Making practice.

6. There is no significant difference between the opinions of academicians and administrators of public and private sector universities about the staff selection. 
7. There is no significant difference between the opinions of academicians and administrators of public and private sector universities about the procedure for irregularities.

\section{METHODOLOGY}

The study was designed to determine the comparison between the opinions of academicians and administrator about selected administrative practices of public and private sector universities of Khyber Pakhtoonkhwa and Punjab. A sample of 320 (160 academicians and 160 administrators) was randomly selected from selected four public and four private sector universities of Khyber Pakhtoonkhwa and Punjab. A questionnaire consisting of 32 domains of administrative practices was used for eliciting the data. The questionnaire was personally administered to the respondents. T-test was used as a statistical technique for analyzing the data.

\section{RESULTS}

Table.1. Comparison between the views of academicians and administrators of public and private sector universities about the amendments in the Act/Statutes

\begin{tabular}{|l|l|l|l|l|l|l|l|}
\hline S.N & Respondents & N & Mean & Std & t & d.f & p-value \\
\cline { 1 - 5 } 1 & Academicians & 160 & 11.85 & 2.67 & .378 & 318 & .706 \\
\cline { 1 - 4 } 2 & Administrators & 160 & 11.96 & 2.64 & & & \\
\hline
\end{tabular}

Note: The result is significant if probability of occurrence (p-value) is equal to or less than 0.05 level

The table (1) shows the testing of significant difference between the opinions of academicians and administrators about the amendments in the statutes of the public and private sector universities of Pakistan. Since $p=0.706>\alpha=0.05$, means that null hypothesis of no significant difference between the opinions of academicians and administrators about the amendments in the act/statutes of the public and private sector universities is accepted. This means academicians and administrators were of the same opinions about the amendments in the Act/statutes of the public and private sector universities of Pakistan.

Table.2. Comparison between the views of academicians and administrators of public and private sector universities about the HEC influence in Administrative matters.

\begin{tabular}{|l|l|l|l|l|l|l|l|}
\hline S.N & Respondents & $\mathbf{N}$ & Mean & Std & t & d.f & p-value \\
\cline { 1 - 5 } 1 & Academicians & 160 & 16.59 & 3.92 & .461 & 318 & .645 \\
\cline { 1 - 4 } & Administrators & 160 & 16.40 & 3.58 & & & \\
\hline
\end{tabular}

The table (2) shows the testing of significant difference between the opinions of academicians and administrators about the HEC influence in Administrative matters of the public and private sector universities of Pakistan. Since $p=0.645>\alpha=0.05$, means that null hypothesis of no significant difference between the opinions of academicians and administrators about the HEC influence in Administrative matters of the public and private sector universities is accepted. 
This means academicians and administrators were of the same opinions about the HEC influence in Administrative matters of the public and private sector universities of Pakistan.

Table.3. Comparison between the views of academicians and administrators of public and private sector universities about the selection of different bodies

\begin{tabular}{|l|l|l|l|l|l|l|l|}
\hline S.N & Respondents & $\mathbf{N}$ & Mean & Std & t & d.f & p-value \\
\cline { 1 - 5 } 1 & Academicians & 160 & 12.42 & 2.07 & .102 & 318 & .919 \\
\cline { 1 - 4 } & Administrators & 160 & 12.45 & 2.31 & & & \\
\hline
\end{tabular}

The table (3) shows the testing of significant difference between the opinions of academicians and administrators about the selection of different bodies of the public and private sector universities of Pakistan. Since $p=0.919>\alpha=0.05$, means that null hypothesis of no significant difference between the opinions of academicians and administrators about the selection of different bodies of the public and private sector universities is accepted. This means academicians and administrators were of the same opinions about the selection of different bodies of the public and private sector universities of Pakistan.

Table 4. Comparison between the views of academicians and administrators of public and private sector universities about the tenure of different bodies

\begin{tabular}{|l|l|l|l|l|l|l|l|}
\hline S.N & Respondents & $\mathbf{N}$ & Mean & Std & t & d.f & p-value \\
\cline { 1 - 5 } 1 & Academicians & 160 & 13.38 & 1.87 & .394 & 318 & .694 \\
\cline { 1 - 4 } & Administrators & 160 & 13.29 & 2.08 & & & \\
\hline
\end{tabular}

The table (4) shows the testing of significant difference between the opinions of academicians and administrators about the tenure of different bodies of the public and private sector universities of Pakistan. Since $p=0.694>\alpha=0.05$, means that null hypothesis of no significant difference between the opinions of academicians and administrators about the tenure of different bodies of the public and private sector universities is accepted. This means academicians and administrators were of the same opinions about the tenure of different bodies of the public and private sector universities of Pakistan.

Table.5. Comparison between the views of academicians and administrators of public and private sector universities about the Decision making practice.

\begin{tabular}{|l|l|l|l|l|l|l|l|}
\hline S.N & Respondents & $\mathbf{N}$ & Mean & Std & t & d.f & p-value \\
\cline { 1 - 5 } 1 & Academicians & 160 & 9.12 & 1.93 & .470 & 318 & .638 \\
\cline { 1 - 4 } 2 & Administrators & 160 & 9.22 & 1.86 & & & \\
\hline
\end{tabular}

The table (5) shows the testing of significant difference between the opinions of academicians and administrators about the Decision Making practice of the public and private sector universities of Pakistan. Since $p=0.638>\alpha=0.05$, means that null hypothesis of no significant difference between the opinions of academicians and administrators about the decision making practice of the public and private sector universities is accepted. This means 
academicians and administrators were of the same opinions about the decision making practice of the public and private sector universities of Pakistan.

Table 6. Comparison between the views of academicians and administrators of public and private sector universities about the staff selection.

\begin{tabular}{|l|l|l|l|l|l|l|l|}
\hline S.N & Respondents & $\mathbf{N}$ & Mean & Std & t & d.f & p-value \\
\cline { 1 - 5 } 1 & Academicians & 160 & 10.42 & 1.78 & .275 & 318 & .784 \\
\cline { 1 - 4 } & Administrators & 160 & 10.37 & 1.44 & & & \\
\hline
\end{tabular}

The table (6) shows the testing of significant difference between the opinions of academicians and administrators about the staff selection in public and private sector universities of Pakistan. Since $p=0.784>\alpha=0.05$, means that null hypothesis of no significant difference between the opinions of academicians and administrators about the staff selection Procedure in public and private sector universities is accepted. This means that views of both academicians and administrators are not different about the staff selection in public and private sector universities.

Table 7. Comparison between the views of academicians and administrators of public and private sector universities about the procedure for irregularities.

\begin{tabular}{|l|l|l|l|l|l|l|l|}
\hline S.N & Respondents & N & Mean & Std & t & d.f & p-value \\
\cline { 1 - 5 } 1 & Academicians & 160 & 10.625 & 1.831 & 2.612 & 318 & .009 \\
\cline { 1 - 5 } & Administrators & 160 & 11.150 & 1.763 & & & \\
\hline
\end{tabular}

The table (7) shows the testing of significant difference between the opinions of academicians and administrators about the procedure for irregularities of the public and private sector universities of Pakistan. Since $p=0.009<\alpha=0.05$, means that null hypothesis of no significant difference between the opinions of academicians and administrators about procedure for irregularities amendments in the statutes of the public and private sector universities is rejected. This means academicians and administrators were of the different opinions about the procedure for irregularities of the public and private sector universities of Pakistan.

\section{Discussion and Conclusions}

The study investigated the comparison of selected administrative practices in public and private sector universities of Pakistan. The selected administrative practices were the amendments in the act/statute, the HEC influence in Administrative matters, the selection of different bodies, tenure of different bodies, the Decision Making practice, and the staff selection and procedure for irregularities. No significant difference was found between the administrators and academicians about the amendments in the Act/statutes, the HEC influence in Administrative matters, the selection of different bodies, tenure of different bodies, the Decision Making practice, and the staff selection and procedure for irregularities of public and 


\section{Ml Macrothink}

private sector universities of Pakistan, means the procedure for amendments of Act/statutes is same in both public and private sector universities of Pakistan.

And HEC which is a coordinating body between universities is working on the equal ground in both public and private sector universities.

For the best operation of different matters of day to day activities each university of the Pakistan and other countries of the world has different executing bodies i.e. senate, syndicate, academic council, advance studies and research board, etc the names may be different whether it is private or public sector have same procedure for selecting the members and their tenure. Decision making practice is very important and seen in day to day activities and procedure of different matters of the universities. The university executive and legislative level bodies make decisions which affect the total system; Valero (1997) found these bodies implement various policies and strategies for operation and upholding of organizational structure of university system. Decision making practice is found similar in both sectors public and private. (Anwar, 2008). Investigated unsatisfactory condition about decision making practice in universities of Pakistan.

Teaching faculty which is working as a backbone in the any educational institute, who Gregorian (2005) names as the "heart and soul, the bone marrow and blood of universities (cited by (Gonzales, 2010)) of the university, its selection procedure is found same in both sectors.

While significant difference was found about the procedure for any irregularities between the opinions of academicians and administrators in public and private sector universities of Pakistan. It is evident that there is lack of a proper procedure for dealing with irregularities in both sector universities 


\section{REFERENCES}

2012, Vol. 2, No. 1

Abdullah, S. (1992). Stray thoughts on education in Pakistan. Lahore: Pakistan Aziz.

Adeeb, M. (1996). Comparative Study of developed \& developing Countries. Multan: Beacon Books.

Aeth, R. (1975). Education \& Development in Third World . Hants, UK: Saxon House Lamington.

Allen, M. ((1988)). The goal of universities. The Society for Research into .

Anwar, M. N. (2008). Decision Making Practices In Universities Of Pakistan. Journal of Diversity Management, Volume 3 (Number 4).

Gonzales, L. D. (2010). Faculty insid a changing University: Constructing Roles, Making Spaces. Retrieved oct0ber 12th , 2011, from www.eric.gov.com: http://www.eric.ed.gov/ERICWebPortal/search/recordDetails.jsp?searchtype=basic\&pageSiz e=10\&ERICExtSearch_SearchValue_0

Haider, S. Z. (2008). Challenges in Higher Education: Special reference to Pakistan and South Asian. Nonpartisan Education Review, Volume, 4 (Issue,2).

Loh Benjamin, A.-C. T.-W. (2003). APPLYING KNOWLEDGE MANAGEMENT IN. Retrieved september 20-09-2011, 2011, from http://www.uni-bonn.de: http://www.uni-bonn.de/ hevers/papers/Loh-Tang-Menkhoff-Chay-Evers2003-new.pdf Mishra, M. (2007). Modern Methods of Educational Administration. New Delhi: Navprabhat Printing Press.

Mohanty, j. (1998). Educational administration supervision and school management. new delhi: Oxford \& IBH publising Co. Pvt. Ltd.

Pakistan, G. o. (1998-2010). National Educational Policy. Islamabad: Ministry of Education. Quddus, N. (1990). Problems of education in Pakistan. Royal Book: Karachi, Pakistan.

Quddus, N. (1990). Problems of education in Pakistan. Royal Book: Karachi, Pakistan.

R.J. Matthai, U. a. (1992). Management process in Universities. New Dehi: Oxford \& IBH Publishing Company Private Ltd.

Singh, V. (1978). A Comprative Study of Administration of Selected Universities in India and Abroad. Vedya Bhawan Teachers College Udaipur (Udaipur): un published thesis.

Vohra A.M., S. S. (1990). Management of Higher Education in India. New Delhi: Anmol Publishers. 